\title{
Evaluation of earnings of small and medium- sized enterprises in Slovakia in aspect of globalization
}

\author{
Veronika Jurickova ${ }^{1, *}$, and Anna Kubjatkova ${ }^{1}$ \\ ${ }^{1}$ University of Zilina, Faculty of Operation and Economics of Transport and Communications, \\ Department of Economics, Univerzitna 1, 01026 Zilina, Slovakia
}

\begin{abstract}
.
Research background: Small and medium-sized enterprises are a pillar of every market economy in aspect of globalization. The importance of their position is given mainly by their positive effect on employment. One of the basic elements of healthy economic development in the country is the dynamic increase of these companies, which can satisfy the requirements of even the most demanding customers with their high adaptability and creativity.

Purpose of the article: The main goal of the article is to examine the profits of small and medium-sized enterprises from 2015 to 2019. The article also contains the characteristics of small and medium-sized enterprises and their contribution to the economy of the Slovak Republic. The contribution of the article lies in a summary of theoretical knowledge about small and medium-sized enterprises and an examination of the reasons why there was an increase or decrease in profit in individual years. Methods: The scientific method of analysis was used in writing the article, where we came to the appropriate conclusions based on the examination of individual parts. The individual years were compared with each other using the method of mutual comparison.

Findings \& Value added: The output of the whole article is the finding that small and medium-sized enterprises represent an important part of the economy of the Slovak Republic. In the Slovak republic, the constant support and development of these businesses are essential because they have a significant impact on many economic indicators.
\end{abstract}

Keywords: small and medium-sized enterprises; earnings; economic indicators

JEL Classification: $D 49 ; M 21$

\footnotetext{
* Corresponding author: veronika.galgankova@,fpedas.uniza.sk.
} 


\section{Introduction}

In the literature, the authors define small and medium-sized enterprises according to various criteria. The definition of a category of small and medium-sized enterprises cannot be determined on the basis of one criterion. According to the subject of activity, it is possible to distinguish between production and providing services. Small businesses are more service-oriented, in various activities such as business enterprises, transport enterprises, banking enterprises, travel agencies, construction, accommodation, etc. According to ownership, we divide companies into private, public, and mixed [1]. In small businesses, private ownership predominates the most often. From the point of view of legal form, we divide companies into companies of individuals and companies. Small business is also characterized by the fact that the entrepreneur and the owner are the same people. Medium enterprises are enterprises of entrepreneurs, capital companies, commercial companies, or maybe also mixed [2].

In today's global world, small and medium-sized enterprises must constantly come to market with new strategies in order to compete and succeed in the global market. In their study, the authors Linan, Paul, and Fayolle examined theoretical models focused on the application of small and medium-sized enterprises in the market in the conditions of globalization [3].

The characteristics of SMEs can be determined on the basis of qualitative characteristics as well as quantitative features. From a quantitative point of view, the term SME includes all areas which do not exceed a certain size. Statistical determination of the size of the company is complicated, and so they were looking for indicators of the size of the company. In some countries, a larger one has been defined number of indicators such as the size of profit, investment, type of capital, market share of the company, the volume of production and sales, number of jobs. All these criteria can be included as technical-quantitative criteria, they have a number of weaknesses because each criterion has limited explanatory power [4].

The author Kupkovic defines small enterprises as separate units, which are owned by an individual or only a small number of owners. Businesses have a small number of employees also small turnover, capital, and profit. According to this author, medium and small enterprises are small businesses focused on satisfying the demand for individual products and services [5]. Usually, small businesses are built close to the customer so that small businesses can react quickly to their request. It is a cooperation of companies, where large companies are surrounded by large one's number of small suppliers, such as parts, components. Large enterprises are independent enterprises and units with high turnover, large capacity, and also a large number of employees. Large companies often dictate conditions to other entities on the market and do business in large-scale and mass production [6]. They are used mainly in the extraction of raw materials, metallurgy, and engineering. Small and large companies in the market do not stand against each other, but together effectively fill the market. This is so that large companies cover demand through mass production and market gaps for the demands of individual production of goods for small businesses [7].

The authors Makkonen and Leick examined the impact of small and medium-sized enterprises on their border location. Their research has shown that these companies benefit from their location, in particular from their borderline location. They also found that these companies are negatively affected by externalities that stem from their location [8].

Small and medium-sized enterprises are the basis of economic growth, as are individual entrepreneurs. Businesses as well as individualists are an essential part of stimulating innovation in individual countries. At present, however, there are many gaps in research that 
deal with this issue. A review of the literature in the field was prepared by Dabic, Maley, et al [9].

Making a profit is one of the main goals and stimuli of business. Profit at the same time expresses the success of an enterprise over a period of time, achieved through an activity that performs. Regular monitoring is necessary to maintain a positive development and profit value factors affecting its height. In an unfavorable situation, the company is able to accept in time certain measures to mitigate the possible negative consequences [10].

The data on the economic result is one of the most important data on corporate finance reports, which attracts the attention of almost all users of the reports. It summarizes the quality and efficiency of all business processes and contributes to expressing the overall effect of the company's activities in a given period [11].

Prediction of financial health and financial situation is an essential part of every business and provides important information not only to the business itself but also to investors, stakeholders, and the public [12].

Profit is the result of the company's management - it is the difference between total revenues and total costs. If the revenues exceed the costs, a profit is made, but if the revenues are lower as a cost a loss arises. Profit and profitability (profitability) are crucial for strategic and tactical business decision-making. The criterion of the decision - making in business management is profit maximization. But we can not forget that more profit (return on investment capital) is associated with risk - the higher the expected profit, the higher the risk - the profit is the main source of the company.

Polach lists 4 profit functions:

- $\quad$ criteria - decision-making on economic issues of the company.

- Accumulation - the creation of financial resources for business development.

- Distributive - payment of funds to owners (dividends), investors (interest), and the state (taxes).

- Motivational - profit acts as the main motivator of business and involvement workers [13].

Kosco considers as profit a situation where revenues exceed costs, but adds that it also represents the efficiency of use capital, is a source of income for owners, and a significant source of financing for the company and its further development [14].

According to Dvoracek, the profit is both a quantitative and qualitative indicators. Quantitative indicators due to the possibility of expression in monetary units. Qualitative indicator because it reflects the prosperity of the company. He states that profit (or loss) is an indicator of the economic activity of the enterprise, as it reflects the level of the entire enterprise activities, namely production, supply, sales, management, etc [15].

From another point of view brings Samuelson and Nordhaus, according to which the profit is primarily the income of the owners of the company from the factors of production capital and labor they provided to the company [16].

Several indicators can be used to measure the economic profit of a company. One of them is the use of economic added value, which is an important indicator of measuring the company's performance [17].

\section{Methods}

The main goal of the article is to describe the profits of small and medium-sized enterprises in the Slovak Republic, to determine the number of small and medium-sized enterprises, and to evaluate their importance for the country's economy. The article also provides an overview of support and barriers for this type of business in the country. The data needed to 
write the article were obtained from works and research by Slovak and foreign authors related to this issue. A positive benefit of the article is the use of scientific articles, proceedings, and publications from the Web of Science, Scopus, journals such as Small Business Economics: An Entrepreneurship Journal.

\subsection{Classification of SME}

An enterprise can be classified as an SME only if it meets the main criterion, the number of employees, and one other criterion.

Table 1. Classification of SME

\begin{tabular}{|l|l|l|l|}
\hline Enterprise category & Headcount & Turnover & Balance sheet total \\
\hline medium-sized & $<250$ & $\leq 50$ million euro & $\leq 43$ million euro \\
\hline Small & $<50$ & $\leq 10$ million euro & $\leq 10$ million euro \\
\hline Micro & $<10$ & $\leq 2$ million euro & $\leq 2$ million euro \\
\hline
\end{tabular}

The number of employees and the financial amounts are obtained from the financial statements for the last approved accounting period and are calculated on an annual basis. The amount of annual turnover is to be calculated net of value-added tax (VAT) and other indirect taxes. Also, if an enterprise finds on the balance sheet date that the number of employees or financial limits has been exceeded, it does not automatically mean the loss of the status of medium, small or micro-enterprise. However, the situation will change if these limits are exceeded in two consecutive periods. In the case of start-ups, the data obtained by estimation apply.

\section{Results}

According to the SBA agency, which obtains data from the Statistical Office of the Slovak Republic, up to $99.9 \%$ of small and medium-sized enterprises occur in Slovakia out of the total number of active entrepreneurs. It follows that the number of large companies, which employ more than 250 employees and have an annual turnover of more than 50 million euros, is not widespread in Slovakia. Therefore, another characteristic of enterprises will be focused on small and medium-sized enterprises, which are dominant in Slovakia [18].

Table 2. Number of SMEs in the Slovak Republic from 2014 to 2019

\begin{tabular}{|c|c|c|c|c|c|c|}
\hline & $\mathbf{2 0 1 4}$ & $\mathbf{2 0 1 5}$ & $\mathbf{2 0 1 6}$ & $\mathbf{2 0 1 7}$ & $\mathbf{2 0 1 8}$ & $\mathbf{2 0 1 9}$ \\
\hline Total & 565,241 & 531,063 & 557,122 & 542,893 & 559,841 & 595,371 \\
\hline $\begin{array}{c}\text { Natural } \\
\text { persons - } \\
\text { entrepreneurs }\end{array}$ & 369,514 & 338,467 & 346,992 & 323,948 & 330,377 & 349,018 \\
\hline Legal persons & 195,727 & 192,596 & 210,130 & 218,945 & 229,464 & 246,353 \\
\hline
\end{tabular}

In Slovakia, small and medium-sized enterprises have the largest representation of the total number of active entrepreneurs. This situation is not only in Slovakia but also in statistics of the Member States of the European Union about small and medium-sized enterprises are similar. SMEs can therefore be considered the basis of every country's economy. 
Table 2. expresses the absolute number of SMEs in the Slovak Republic from 2014 to 2018. In 2014, 525,421 SMEs were registered in the country, of which 369,514 were natural persons- entrepreneurs and 195,727 legal persons.

In 2014, there was a significant reduction in the number of the new business largely due to the introduction of tax licenses. This decline lasted until 2015, after which interest in entrepreneurship began to increase again every year. In 2015, 531,063 small and mediumsized enterprises registered in Slovakia. Year-on-year, the total number of small and medium-sized enterprises decreased by $6.0 \%$. The reason for this reduction was mainly the establishment of a new methodology for determining the activity of entities. Of the total number, there were 338,467 natural persons- entrepreneurs and 192,596 legal persons.

Compared to 2015, there was a positive increase in the number of SMEs in Slovakia in 2016. Their number increased by $4.9 \%$, to 557,122 by 26,059 . The number of legal persons increased by $9.1 \%$ and the number of natural persons - entrepreneurs increased by $2.5 \%$ year-on-year.

In 2017, there was a year-on-year increase in the number of active small and mediumsized enterprises. The data show that their number increased by $1.8 \%$ compared to 2016 . In terms of absolute numbers, the number of small and medium-sized enterprises increased to 567,793 in 2017 . The increase in numbers is mainly due to an increase in the number of small and medium-sized enterprises - legal persons by $4.1 \%$, to a total of 248,945 . Amount of natural persons increased only by at least $0.4 \%$, to 323,948 .

The number of SMEs also increased in 2018. Within the structure of SMEs according to legal forms, natural persons - entrepreneurs still predominate with a share of $59.0 \%$, which in absolute terms represents 330, 377 persons. The representation of SMEs - legal persons in 2018 reached 229,464 in 2018. This significant increase was mainly due to an increase in the amount of lump sums expenditure that self-employed persons can claim from 2018 from $40 \%$ of total income to $60 \%$ together with an increase in the annual limit from EUR 5, 040 to EUR 20, 000 and reduction in income tax legal entities from $22 \%$ to $21 \%$ and the abolition of tax licenses.

In 2019, the number of small and medium-sized enterprises increased significantly to 595,371 . The number of natural persons-entrepreneurs increased to 349,018 and the number of legal persons increased to 246,353 [19].

Table 3. Earnings of SME in mil. $€$

\begin{tabular}{|l|c|c|c|c|c|}
\hline Category & $\mathbf{2 0 1 5}$ & $\mathbf{2 0 1 6}$ & $\mathbf{2 0 1 7}$ & $\mathbf{2 0 1 8}$ & $\mathbf{2 0 1 9}$ \\
\hline $\mathbf{0 - 9}$ & $1,213.6$ & $1,383.2$ & $2,272.6$ & $2,692.0$ & $2,492.7$ \\
\hline $\mathbf{1 0 - 4 9}$ & $1,682.1$ & $1,821.2$ & $1,297.1$ & $1,699.4$ & $1,654.8$ \\
\hline $\mathbf{5 0 - 2 4 9}$ & $1,582.8$ & $1,423.1$ & $1,404.5$ & $1,499.0$ & $1,282.8$ \\
\hline
\end{tabular}

EAT (Earnings After Taxes) is the net profit that an enterprise has to distribute among owners after fulfillment of tax liability. Represents the result of the enterprise from the main activity which includes the effect of income tax. In connection with it, NI (Net Income), which expresses the economic result reduced by the tax paid [20].

The year 2018 was the most successful year in assessing the profits of small and medium-sized enterprises in the Slovak Republic. On the other hand, the lowest profits were achieved in 2015 for enterprises with up to 9 employees. For companies with 249 employees, the year 2019 was the least successful.

Activities aimed at supporting small and medium-sized enterprises can be broadly divided into two basic groups:

- financial support, 
- information support.

In terms of the origin and location of the support, it is possible to divide the entities providing both forms of support into three groups:

- government organizations focused on providing various services for entrepreneurs,

- non-governmental organizations (usually non-profit),

- business entities [21].

The current system of support for small and medium-sized enterprises in the Slovak Republic is constantly updated, although it cannot be considered fully satisfactory. The basic elements of the support system are formed by the ministries, in particular the Ministry of Economy, the Slovak Guarantee, and Development Bank and the National Agency for the Development of Small and Medium-sized Enterprises (NADSME).

Barriers to doing business in the Slovak Republic are divided into internal and external barriers. Internal barriers are barriers that can be a source of failure but can be easily removed by appropriate methods. Internal barriers are in particular:

- weak motivation,

- fear of risk,

- bad information,

- insufficient business strategy,

- accounting problems,

- lack of capital.

External barriers arise from the external environment of the company and cannot be easily removed. External barriers include:

- administrative and time-consuming nature of establishing a company - establishing a company in the Slovak Republic takes an average of 26-27 days. It requires a lot of actions, which is time-consuming for entrepreneurs.

- Limited access to credit and finance - even though the business plan is profitable, entrepreneurs have limited access to commercial credit because banks are reluctant to lend to them due to their short history.

- High tax burden - high employer contributions per employee, income tax, real estate tax, interest tax, and others.

- Opacity and incomprehensibility of laws - in the Slovak Republic, laws and business conditions are constantly changing, which causes excessive administrative demands. It is one of the priority barriers to business that needs to be removed [22].

- Poor law enforcement and lengthy litigation - the time to resolve litigation take 775 days, and this number has increased by 70 days since the last assessment. Litigation and its costs are most pronounced for small businesses.

- Improper length of obtaining building permits - Slovakia is one of the worst countries in Central Europe in terms of the length of obtaining a building permit. The permit for the construction of a warehouse lasts 286 calendar days in Slovakia, which objectively hinders the further development of the company.

- Barriers to entry for new companies into the sector from the competition - new companies have a big problem staying in the market due to strong competition. Due to a large number of small and medium-sized enterprises, the new enterprise has great difficulty gaining a foothold in the sector [23].

Small and medium-sized enterprises in the Slovak Republic represent strong economic development potential. The state and also The European Union are aware that the area of support for small and medium-sized enterprises is important for the economy and for their competitiveness. In order to achieve the competitiveness of companies, it is necessary to maintain sufficient financial health of the company, which also reduces the possibility of risks. Several indicators, methods, and analyzes can be used to assess financial health [24]. 
Micro, small and medium-sized enterprises can be seen as the driving force of national one's economies, but also the economies of the European Union, as they create the right conditions for increasing employment, for the implementation of innovation processes, but also create a suitable social environment in the regions. Their flexibility predestines them to become a stabilizing regional factor, even today, at a time of increasing competitive pressures and the global economic crisis [25]. For these reasons, it is necessary to support SMEs, whether in a financial or advisory basic direction of their further development.

\section{Discussions}

Entrepreneurship in small and medium-sized enterprises in the Slovak Republic is characterized mainly by its flexibility. Small and medium-sized enterprises can adapt to changing market conditions very quickly. In terms of numbers, small and medium-sized enterprises have the largest representation not only in Slovakia but in the whole of Europe. Despite the great importance of small and medium-sized enterprises, there are barriers in the Slovak Republic that can negatively affect their activities. Constantly changing legislation, high taxes, and insufficient access to credit often lead to these businesses disappearing. Barriers also affect entrepreneurs who want to enter the market. When starting a business, they rely on a number of administrative duties that are time-consuming.

In terms of the number of small and medium-sized enterprises, they are constantly growing permanently. The most successful year can be considered the year 2019 when the number of companies was the highest. When evaluating the profits that companies made, the highest profits were achieved in 2018.

For the Slovak economy, small and medium-sized enterprises represent a large part of tax revenues, value-added, help reduce unemployment, contribute to leveling out the regional differences. They are also very ecologically important because they disperse production throughout Slovakia and contribute to the protection of the competitive environment. The state should support the development of this type of enterprise. Support for the SME sector has become an important component of the economic strategy of economically developed countries. This support is provided by governmental organizations with a focus on providing services for entrepreneurs, non-governmental organizations, and business entities. The European Union also plays an important role in supporting SMEs, supporting the development of SMEs through funds earmarked for different programming periods. The involvement of SMEs in various programs and the use of support helps to advance, develop, and increase the competitiveness of SMEs, as well as improve the overall business environment. The basic condition for development is to increase its competitiveness and constant support.

The paper is an output of the science project VEGA: 1/0210/19 Research of innovative attributes of quantitative and qualitative fundaments of the opportunistic earnings modeling.

\section{References}

1. Pisar, P., Bilkova, D. (2019). Controlling as a tool for SME management with an emphasis on innovations in the context of Industry 4.0. Equilibrium. Quarterly Journal of Economics and Economic Policy, 14(4), 763-785.

2. Chodasova, A., Bujnova D. (2008). Podnikanie v malých a stredných podnikoch. Bratislava: Ekonomist. 
3. Linan, F., Paul, J., Fayolle, A. (2020). SMEs and entrepreneurship in the era of globalization: advances and theoretical approaches. Small Business Economics: An Entrepreneurship Journal, 55(3), 695-703.

4. Strazovska, E., Strazovska, L. (1999). Malé a stredné podniky. Bratislava: Economist.

5. Kupkovic, M. et al. (2003). Podnikové hospodárstvo. Bratislava: Sprint.

6. Milanovic, J. (2020). Analysis of the competitiveness of the sector of small and medium enterprises and entrepreneurs in the Republic of Serbia. International Review, (1-2), 128-135.

7. Whittle, T., Gregova, E., Podhorska, I., Rowland, Z. (2019). Smart Manufacturing Technologies: Data-driven Algorithms in Production Planning, Sustainable Value Creation, and Operational Performance Improvement. Economics, Management, and Financial Markets, 14(2), 52-57.

8. Makkonen, T., Leick, B. (2020). Locational challenges and opportunities for SMEs in border regions. European Planning Studies, 28(10), 2078-2098.

9. Dabic, M., Maley, J., Dana, L.P., Novak, I., Pellegrini, M.M., Caputo, A. (2019) Pathways of SME internationalization: a bibliometric and systematic review. Small Business Economics: An Entrepreneurship Journal, 55(3), 705-725.

10. Onuferova, E., Cabinova, V., Vargova, T. D. (2020). Analysis of modern methods for increasing and managing the financial prosperity of businesses in the context of performance: a case study of the tourism sector in Slovakia. Oeconomia Copernicana, 11(1), 95-116.

11. Valaskova, K., Bartosova, V., Kubala, P. (2019). Behavioural Aspects of the Financial Decision-Making. Organizacija, 52(1), 22-31.

12. Durica, M., Svabova, L., Frnda, J. (2019). Decision tree based model of business failure prediction for Polish companies. Oeconomia Copernicana, 10(3), 453-469.

13. Polach, J. (2012). Reálné a finanční investice. Praha: C.H. Beck.

14. Kosco, T., Szovics, P., Sebo, A., Toth, M. (2006). Podnikové financie, 1st ed. Nitra: SPU.

15. Dvoracek, J. (2005). Audit podniku a jeho operaci, 1st ed. Prague: C. H Beck.

16. Samuelson, P. A., Nordhaus, W. D. (2010). Economics. New York: Tata McGraw-Hill Education.

17. Salaga, J., Bartosova, V., Kicova, E. (201). Economic Value Added as a measurement tool of financial performance. Procedia Economics and Finance, 26, 484-489.

18. Lukac, J. (2018). Vznik a zánik malých a stredných podnikov na Slovensku v r. 2017. Bratislava: Slovak Business Agency.

19. Small and medium business in numbers in 2019. (2020). Retrieved from: http://www.sbagency.sk/sites/default/files/male_a_stredne_podnikanie_v_cislach_v_ro ku_2019.pdf

20. Kislingerova, E., Hnilica, J., Steker, K. (2008). Finanční analýza: krok za krokem. Prague: C.H. Beck.

21. Veber, J., Srpova, J. et al. (2005). Podnikání malé a střední firmy. Prague: City Publishing.

22. Gray-Hawkins, M., Michalkova, L., Suler, P., Zhuravleva, N.A. (2019). Real-Time Process Monitoring in Industry 4.0 Manufacturing Systems: Sensing, Smart, and 
Sustainable Technologies. Economics, Management, and Financial Markets, 14(4), 30-36.

23. Comparison of SME business conditions in Central European countries. (2018). Bratislava: Slovak Bussines Agency. Retrieved from: http://www.sbagency.sk/sites/default/files/porovnanie_podmienok_podnikania_msp_v_krajinach_strednej_eur opy.pdf

24. Kliestik, T., Valaskova, K., Lazaroiu, G., Kovacova, M., Vrbka, J. (2020). Remaining Financially Healthy and Competitive: The Role of Financial Predictors. Journal of Competitiveness, 12(1), 74-92.

25. Reicher, Z.R. (2019). Opportunities for small and medium sized enterprises in the field of corporate social responsibility. Ekonomicko-manazerske Spektrum, 13(1), 26-37. 